\title{
Kejang pada Neonatus, Permasalahan dalam Diagnosis dan Tata laksana
}

\section{Setyo Handryastuti}

Divisi Neurologi Departemen Ilmu Kesehatan Anak Fakultas Kedokteran Universitas Indonesia Rumah Sakit Dr. Ciptomangunkusumo, Jakarta

\begin{abstract}
Kejang pada neonatus sulit didiagnosis karena ada beberapa gejala yang tidak khas sehingga terjadi keterlambatan atau diagnosis yang berlebihan. Demikian juga dalam hal tata laksana seringkali kita hanya terpaku pada pemberantasan kejang sehingga upaya untuk mencari dan mengobati etiologi terlambat dan kurang tepat. Selain itu masih terdapat kontroversi dalam hal tata laksana kejang terutama pemilihan obat antikonvulsan yang tepat. Deteksi kejang secara dini, penelusuran etiologi serta tata laksana yang mencakup pemberantasan kejang dan terapi spesifik terhadap etiologi sangat menentukan mortalitas dan morbiditas neonatus. (Sari Pediatri 2007; 9(2):112-120).
\end{abstract}

Kata kunci: kejang neonatus, diagnosis, tata laksana

K ejang pada neonatus sering ditemukan dan merupakan satu-satunya gejala disfungsi susunan saraf pusat pada neonatus, ${ }^{1}$ sulit dideteksi, sukar diberantas serta berkaitan erat dengan mortalitas dan morbiditas seperti epilepsi, palsi serebral dan keterlambatan perkembangan di kemudian hari. ${ }^{2}$ Deteksi dini, mencari etiologi dan memberikan tata laksana yang adekuat sangat penting pada kejang neonatus. (1) Kejang umumnya berkaitan dengan penyakit berat yang memerlukan terapi

\author{
Alamat korespondensi \\ dr. Setyo Handryastuti, SpA \\ Divisi Neurologi Anak FKUI-RSCM Jl. Salemba No. 6, Jakarta 10430, \\ Indonesia \\ Telpon : (021) 3149161. e-mail : handryabdullah@yahoo.com
}

spesifik, (2) Kejang mempengaruhi tindakan suportif seperti alat bantu nafas dan alimentasi yang sering diberikan pada neonatus dengan penyakit tertentu, (3) Kejang dapat menyebabkan kerusakan otak. ${ }^{1,3}$

Insidens kejang pada neonatus dibedakan menurut berat badan lahir, yaitu 57,5 per 1000 bayi dengan berat lahir $(\mathrm{BL})<1500 \mathrm{~g}, 4,4$ pada bayi dengan $\mathrm{BL}$ 1500-2499, 2,8 pada bayi dengan BL 2500-3999 g, serta 2,0 pada bayi $\mathrm{BL}>4000$ g. ${ }^{4,5}$

\section{Definisi}

Definisi kejang adalah depolarisasi berlebihan sel-sel neuron otak, yang mengakibatkan perubahan yang bersifat paroksismal fungsi neuron (perilaku, fungsi motorik dan otonom) dengan atau tanpa perubahan 
kesadaran. ${ }^{6}$ Kejang pada neonatus dibatasi waktu yaitu kejang yang terjadi pada 28 hari pertama kehidupan (bayi cukup bulan) atau 44 minggu masa konsepsi (usia kronologis + usia gestasi pada saat lahir) pada bayi prematur. $^{7}$

\section{Patofisiologi}

Depolarisasi berlebihan sel-sel neuron otak terjadi akibat masuknya ion natrium ke dalam sel, sedangkan repolarisasi diakibatkan oleh keluarnya ion kalium ke ekstra sel. Fungsi neuron adalah menjaga keseimbangan antara depolarisasi dan repolarisasi. Jika terjadi depolarisasi maka terjadi potensial aksi yang mengakibatkan penglepasan neurotransmiter dari presinaps di terminal akson. Neurotransmiter akan berikatan dengan reseptor postsinaps dan menghasilkan potensial aksi yang dapat bersifat eksitasi atau inhibisi. Fungsi otak normal sangat bergantung dari keseimbangan antara eksitasi dan inhibisi. ${ }^{8}$

Keseimbangan membran potensial membutuhkan enerji yang berasal dari adenosine triphospate (ATP) yang menggerakkan pompa $\mathrm{Na}-\mathrm{K}$ yang berfungsi mengeluarkan ion kalium dan memasukkan ion natrium. ${ }^{9}$ Meskipun mekanisme terjadinya kejang pada neonatus belum diketahui secara pasti, namun terdapat beberapa teori yang menerangkan depolarisasi berlebihan, yaitu' (1) Pompa Na-K tidak berfungsi akibat kekurangan enerji, disebabkan oleh hipoksikiskemik dan hipoglikemia. (2) Neurotransmiter eksitasi (glutamate) yang berlebihan (produksi yang berlebih atau berkurangnya re-uptake) sehingga mengakibatkan depolarisasi yang berlebihan, ditemukan pada keadaan hipoksik-iskemik dan hipoglikemia. (3) Defisiensi relatif neurotransmiter inhibisi (gama-amynobutiric acid (GABA) mengakibatkan depolarisasi berlebihan, hal ini terjadi akibat menurunnya aktivitas enzim glutamic acid decarboxylase pada keadaan defisiensi piridoksin. (4) Terganggunya permeabilitas membran sel, sehingga ion natrium lebih banyak masuk ke intrasel yang mengakibatkan depolarisasi berlebihan, ditemukan pada hipokalsemia dan hipomagnesemia karena ion kalsium dan magnesium berinteraksi dengan membran sel untuk menghambat masuknya ion natrium.

Kejang pada neonatus berbeda dari kejang pada bayi, anak maupun orang dewasa demikian pula manifestasi kejang pada bayi prematur berbeda dibandingkan bayi cukup bulan. ${ }^{8}$ Kejang neonatus lebih bersifat fragmenter, kurang terorganisasi dan hampir tidak pernah bersifat kejang umum tonik klonik. Kejang pada bayi prematur lebih tidak terorganisasi dibandingkan dengan bayi cukup bulan, berkaitan dengan perkembangan neuroanatomi dan neurofisiologi pada masa perinatal. ${ }^{8}$

Organisasi korteks serebri pada neonatus belum sempurna, selain itu pembentukan dendrit, akson, sinaptogenesis dan proses mielinisasi dalam sistem eferen korteks belum selesai. Imaturitas anatomi tersebut mengakibatkan kejang yang terjadi tidak dapat menyebar ke bagian otak yang lain sehingga tidak menyebabkan kejang umum. Daerah subkorteks seperti sistem limbik berkembang lebih dahulu dibandingkan daerah korteks dan bagian ini sudah terhubung dengan diensefalon dan batang otak sehingga kejang pada neonatus lebih banyak bermanifestasi gerakan-gerakan oral-buccal-lingual movements seperti menghisap. mengunyah, drooling, gerakan bola mata dan apnea. ${ }^{1}$

Hubungan antara sinaps eksitasi dan inhibisi merupakan faktor penentu apakah kejang yang terjadi akan menyebar ke daerah lain. Ternyata kecepatan

Tabel 1. Etiologi kejang neonatus dihubungkan dengan awitan kejang dan frekuensi ${ }^{1}$

\begin{tabular}{lcccc}
\hline \multirow{2}{*}{ Etiologi } & \multicolumn{2}{c}{ Awitan kejang } & \multicolumn{2}{c}{ Frekuensi relatif } \\
\cline { 2 - 5 } & $0-3$ hari & $>3$ hari & Prematur & Cukup bulan \\
\hline Ensefalopati hipoksik-iskemik & + & & +++ & +++ \\
Perdarahan intrakranial & + & + & ++ & + \\
Infeksi intrakranial & + & + & ++ & ++ \\
Gangguan perkembangan otak & + & + & ++ & ++ \\
Hipoglikemia & + & & + & + \\
Hipokalsemia & + & + & & + \\
Kelainan metabolik lain & + & & & + \\
Sindrom epilepsi & + & + & & + \\
\hline
\end{tabular}


Tabel 2. Etiologi kejang pada neonatus*

\begin{tabular}{lc}
\hline \multicolumn{1}{c}{ Etiologi } & Frekuensi (\%) \\
\hline Ensefalopati hipoksik-iskemik & $30-53$ \\
Perdarahan intrakranial & $7-17$ \\
Infark serebri6-17 & \\
Malformasi serebral & $3-17$ \\
Meningitis/septikemia & $2-14$ \\
Metabolik & \\
$\quad$ Hipoglikemia & $0,1-5$ \\
$\quad$ Hipokalsemia,hipomagnesemia & $4-22$ \\
$\quad$ Hipo/hipernatremia & \\
$\quad$ Inborn errors of metabolism & $3-4$ \\
$\quad$ Defisiensi piridoksin & \\
$\quad$ Kern ikterus & 1 \\
Maternal drug withdrawl & 4 \\
Idiopatik & 2 \\
Benign idiopathic neonatal seizures & 1 \\
Sindrom epilepsy neonatal & \\
Infeksi kongenital & \\
Injeksi anestesi lokal selama persalinan & \\
\hline
\end{tabular}

*Dikutip dari Levene dan Trounce ${ }^{10}$, Lien $\mathrm{dkk}^{11}$, Mizrahi dan Kellaway $^{8}$

perkembangan aktifitas sinaps eksitasi dan inhibisi di otak manusia berbeda-beda. Sinaps eksitasi berkembang lebih dahulu dibandingkan sinaps inhibisi terutama di daerah limbik dan korteks. Selain itu daerah hipokampus dan neuron korteks yang masih imatur lebih mudah terjadi kejang dibandingkan yang telah matur. Belum berkembangnya sistem inhibisi di substansia nigra juga mempermudah timbulnya kejang. ${ }^{1}$

\section{Etiologi}

Etiologi kejang pada neonatus perlu segera diketahui karena menentukan terapi dan prognosis. (Tabel 1 dan 2).

\section{Manifestasi klinis}

Kejang pada neonatus harus dibedakan dari aktifitas normal pada bayi prematur, bayi cukup bulan dan gerakan abnormal lain yang bukan kejang. ${ }^{8}$ Jitteriness merupakan salah satu gejala gangguan pergerakan yang sulit dibedakan dengan kejang. Penyebab tersering jitteriness adalah ensefalopati hipoksik-iskemik, hipokalsemia, hipoglikemia dan gejala putus obat.

Akifitas lain pada neonatus yang menyerupai kejang ${ }^{8}$

1. Pada saat sadar dan mengantuk/drowsy, tampak gerakan bola mata kearah horizontal berupa nystagmoid jerk yang tidak menetap. Dapat dibedakan dari gerakan bola mata pada subtle seizure yang berupa deviasi tonik horisontal bola mata yang menetap, dengan atau tanpa jerking.

2. Pada saat tidur, sering dijumpai myoclonic jerk yang bersifat fragmenter dan multipel. Sering disebut benign neonatal sleep myoclonus.

3. Hiperekpleksia suatu respons yang berlebihan terhadap stimulus (suara atau taktil) berupa mioklonik umum seperti terkejut/kaget (startle response)

4. Klonus

Gerakan-gerakan tersebut dapat dibedakan dari kejang dengan cara menahan gerakan tersebut berhenti. Dengan kemajuan teknologi seperti pemakaian video-EEG monitoring kejang neonatus dapat dibedakan menjadi epileptik dan nonepileptik. Disebut epileptik jika manifestasi kejang berkorelasi kuat dan konsisten dengan aktifitas epileptik pada pemeriksaan EEG. Patofisiologi kejang epileptik disebabkan oleh lepas muatan listrik yang berlebihan dan paroksismal di neuron korteks serta peningkatan eksitasi seluler, sinaps dan aktifitas penyebaran gelombang epilepsi. Disebut non-epileptik jika manifestasi kejang tidak berkorelasi dan atau tidak konsisten dengan aktifitas epileptik pada pemeriksaan EEG. Fokus kejang

Tabel 3. Jitteriness versus kejang ${ }^{1}$

\begin{tabular}{lcc}
\hline \multicolumn{1}{c}{ Manifestasi klinik } & Jitteriness & Kejang \\
\hline Abnormalitas gaze atau gerakan bola mata & 0 & + \\
Gerakan bersifat sensitif terhadap stimulus & + & 0 \\
Gerakan dominan tremor & Clonic jerking & \\
Gerakan berkurang dengan fleksi pasif & + & 0 \\
Perubahan fungsi otonom & 0 & + \\
\hline
\end{tabular}


berasal dari tingkat subkortikal (sistem limbik, diensefalon dan batang otak) dan tidak menyebar ke korteks karena imaturitas pembentukan sinaps serta proyeksi kortikal sehingga tidak dapat atau tidak selalu terdeteksi dengan pemeriksaan EEG. Selain itu kejang yang terjadi bukan akibat dari lepas muatan listrik yang berlebihan tetapi karena cetusan primitif dari batang otak dan refleks spinal yang tidak mendapat inhibisi dari korteks serebri. ${ }^{1,2,8}$

Klasifikasi yang sering dipergunakan untuk menggambarkan manifestasi klinis kejang pada neonatus,

\section{Evaluasi diagnostik}

Riwayat kehamilan, persalinan dan riwayat kejang dalam keluarga sangat diperlukan untuk mencari faktor risiko dan etiologi, setelah itu dilakukan pemeriksaan penunjang. Pendekatan diagnosis sebaiknya dilakukan secara bertahap. Langkah pertama adalah pemeriksaan darah lengkap, gula darah, elektrolit, analisis cairan serebrospinal (CSS), EEG dan pencitraan (Tabel 5). Tujuannya adalah untuk mencari etiologi, memberikan tata laksana yang tepat serta untuk menentukan prognosis. Pemeriksaan ultrasonografi kepala sering merupakan pilihan pertama karena dapat dilakukan bed-side sambil menunggu kondisi neonatus stabil untuk pemeriksaan CT atau MRI. Pemeriksaan CT sangat bermanfaat untuk mendeteksi perdarahan intrakranial akut atau kalsifikasi, sedangkan MRI untuk mengetahui gambaran kerusakan otak yang disebabkan oleh HIE dan melihat disgenesis serebral. ${ }^{14}$

Langkah berikutnya menyingkirkan infeksi dengan pemeriksaan kultur darah dan CSS, serta pemeriksaan PCR dan kultur HSV jika secara klinis dicurigai ensefalitis HSV. Jika penyebab struktural atau infeksi dapat disingkirkan, pikirkan kemungkinan inborn error of metabolism. Asidosis metabolik yang menetap menunjukkan adanya asidemia organik, pemeriksaan amonia diperlukan untuk mendeteksi abnormalitas siklus urea, laktat untuk ensefalopati mitokondria. Pemeriksaan lain yang diperlukan adalah asam amino serum dan asam organik urin. ${ }^{15}$ Riwayat keluarga penting untuk mengetahui ada tidaknya sindrom epilepsi tertentu seperti benign familial neonatal convulsions. ${ }^{14,15}$

Tabel 4. Klasifikasi kejang neonatus ${ }^{1,6,8,12}$

\begin{tabular}{|c|c|c|}
\hline Tipe kejang & Manifestasi klinik & Kelainan gambaran EEG \\
\hline Subtle & $\begin{array}{l}\text { - Oral-buccal-lingual movements } \\
\text { (mouthing,chewing,sucking,smiling) } \\
\text { - Gerak bola mata (staring, blinking, } \\
\text { eye deviation,eye opening) } \\
\text { - Stereotypic pedaling,swimming,stepping } \\
\text { - Gangguan otonom (perubahan tekanan darah, } \\
\text { denyut jantung,pucat,hipersalivasi, apnea) }\end{array}$ & Bervariasi \\
\hline Klonik & $\begin{array}{l}\text { - Rhytmic,slow jerking, kadang sulit } \\
\text { dibedakan dengan jitteriness } \\
\text { - Fokal, multifokal, umum (jarang) } \\
\text { - Fokal : wajah,ekstremitas satu sisi, leher } \\
\text { dan tubuh di satu sisi } \\
\text { - Multifokal: melibatkan beberapa bagian tubuh }\end{array}$ & Sering ditemukan \\
\hline Tonik & $\begin{array}{l}\text { - Sustained posturing tungkai dan atau batang } \\
\text { tubuh atau mata, sering disertai apnea, muka } \\
\text { kemerahan atau sianosis. } \\
\text { - Posisi asimetri dari tubuh dan leher } \\
\text { - Fokal (jarang) atau umum }\end{array}$ & $\begin{array}{l}\text { Fokal : sering ditemukan } \\
\text { Umum : jarang ditemukan }\end{array}$ \\
\hline Mioklonik & $\begin{array}{l}\text { - Rapid, isolated jerks } \\
\text { - Ekstremitas dan tubuh } \\
\text { - Umum,multifokal atau fokal }\end{array}$ & Bervariasi \\
\hline
\end{tabular}




\section{Peran EEG pada kejang neonatus}

Hasil rekaman EEG dapat memberikan konfirmasi apakah gejala yang tampak adalah kejang. Di sisi lain, tidak semua manifestasi kejang bisa terdeteksi dengan EEG terutama pada kejang subtle, sebagian besar kejang umum tonik, kejang mioklonik fokal dan multifokal. Interpretasi EEG interiktal neonatus cukup sulit dan memerlukan keahlian khusus, oleh karena itu untuk meningkatkan akurasi diagnostik dilakukan modifikasi pemeriksaan EEG seperti pemeriksaan EEG secara serial, continuous EEG monitoring, amplitude integrated EEG (aEEG) cerebral function monitoring (CFM) dan synchronized videol EEG recording. ${ }^{2,6}$ Beberapa tahun terakhir pemakaian CFM mulai dikembangkan karena pemakaiannya lebih mudah, dapat dikerjakan bed-side untuk menentukan irama dasar dan aktifitas iktal pada neonatus. Meskipun demikian sekitar 50\% kejang neonatus tidak terdeteksi dengan pemeriksaan CFM. Dianjurkan kejang neonatus pertama kali dikonfirmasi dengan pemeriksaan EEG konvensional, selanjutnya CFM dipakai untuk monitor jangka panjang. ${ }^{15,16}$ Pemeriksaan EEG dan CFM juga dipakai untuk melihat respon terapi antikonvulsan dengan berkurangnya aktifitas epileptiform, serta menentukan lama terapi dan prognosis. ${ }^{17}$

\section{Tata laksana}

Permasalahan dalam tata laksana adalah obat apa yang diberikan pada saat akut dan rumatan, serta berapa lama dan kapan menghentikan obat antikonvulsan tersebut. Prinsip utama dalam tata laksana kejang neonatus adalah, ${ }^{15}$ (1) Mempertahankan ventilasi dan perfusi yang adekuat. (2) Mencari dan memberikan tata laksana terhadap etiologi kejang sesegera mungkin. (3) Tata laksana kejang, dengan mempertimbangkan manfaat pemberantasan kejang dengan efek samping yang mungkin timbul dari pemberian obat antikonvulsan.

Beberapa hal dalam tata laksana kejang masih kontroversi, beberapa peneliti mengatakan bahwa kejang neonatus diobati jika kejang terdeteksi secara klinis dan berkepanjangan, sedangkan kejang elektrik yang terdeteksi melalui pemeriksaan EEG tidak memerlukan terapi. Hal ini menimbulkan kontroversi mengingat kejang elektrik berefek negatif terhadap otak yang immatur. Ketidaksesuaian antara kejang klinis dan elektrik serta singkatnya kejang membuat keraguan kapan antikonvulsan dimulai atau dihentikan. Hal yang perlu diingat adalah neonatus yang mengalami kejang berulang akan mengalami kerusakan otak yang disebabkan oleh gangguan peredaran darah ke otak, metabolisme, dan pernapasan. ${ }^{1,2}$

Tabel 5. Evaluasi diagnostik kejang pada neonatus ${ }^{13}$

\begin{tabular}{ll}
\hline Spesimen pemeriksaan & \multicolumn{1}{c}{ Jenis pemeriksaan } \\
\hline Darah & $\begin{array}{l}\text { Glukosa,elektrolit,kalsium,magnesium,amonia,laktat,analisis } \\
\text { gas darah, evaluasi trombofilia jika dicurigai trombosis arteri } \\
\text { dan vena }\end{array}$ \\
Cairan serebrospinal & $\begin{array}{l}\text { Hitung sel, glukosa, protein, kultur bakteri, pemeriksaan PCR } \\
\text { dan kultur terhadap herpes simplex virus (HSV) jika dicurigai } \\
\text { ensefalitis HSV. Pemeriksaan laktat dan asam amino jika } \\
\text { dicurigai inborn error of metabolism (IEM) } \\
\text { Skrining toksikologi, S-sulfosistein jika dicurigai defisiensi sulfite } \\
\text { oksidase. } \\
\text { Pikirkan defisiensi piridoksin jika etiologi lain dapat } \\
\text { disingkirkan. } \\
\text { EEG }\end{array} \quad \begin{array}{l}\text { Pemeriksaan titer serum pada ibu dan anak, kultur urin untuk } \\
\text { CMV }\end{array}$ \\
Kunining infeksi kongenital \\
Kiwayat keluarga
\end{tabular}


Mizrahi dkk. ${ }^{8}$ menyatakan bahwa pemberian antikonvulsan harus mempertimbangkan beberapa hal yaitu tipe kejang, patofisiologi, lama dan beratnya kejang, perjalanan penyakit etiologi kejang, efek kejang dan obat antikonvulsan terhadap neonatus. Klinisi sering memulai antikonvulsan tanpa melihat gambaran EEG, pada keadaan ini klinisi harus menentukan terlebih dahulu kejang bersifat epileptik atau non epileptik, setelah itu ditentukan lama dan beratnya kejang. Kejang bersifat epileptik jika tidak dapat diprovokasi oleh stimulus dan tidak berhenti dengan reposisi atau tahanan, non epileptik bersifat sebaliknya. ${ }^{8}$ Jika pemeriksaan EEG bed-side atau EEG-video monitoring dapat dilakukan maka pemberian obat antikonvulsan harus mempertimbangan hasil pemeriksaan penunjang tersebut.

Evans dkk. ${ }^{15}$ merekomendasikan pemberian obat antikonvulsan pada kejang yang bersifat lama (lebih dari 3 menit) atau berulang (lebih dari 3 kali perjam), terutama jika mengganggu ventilasi dan tekanan darah.

Obat-obatan yang dipakai dalam tata laksana kejang tertera pada Tabel 6.

Jika pada fase akut pemberian fenobarbital sampai $40 \mathrm{mg} / \mathrm{kg}$ BB belum dapat memberantas kejang, dapat dilanjutkan dengan pemberian fenitoin inisial. Jika tidak terdapat respon dengan kombinasi fenobarbital dan fenitoin, dapat ditambahkan lorazepam. Lorazepam seperti diazepam mempunyai onset yang cepat (kurang dari 5 menit). Kelebihan lorazepam dibandingkan diazepam adalah masa kerja yang lebih panjang (sampai 24 jam), efek depresi pernapasan dan hipotensi yang ditimbulkan lebih ringan. Sedapat mungkin diazepam tidak dipergunakan karena beberapa alasan (1) Masa kerja yang singkat, (2) Kombinasi diazepam dengan fenobarbital meningkatkan risiko kolapsnya kardiovaskular dan gagal napas, (3) Kisaran dosis sangat sempit, dan (4) Pelarut diazepam mengandung natrium benzoat yang mengganggu kompleks bilirubin-albumin., Obat fenobarbital, fenitoin, lorazepam, dan diazepam adalah obat lini pertama, jika dengan obat-obat tersebut kejang belum teratasi, penyebab kejang harus dicari dan diobati termasuk gangguan metabolik seperti IEM, pyridoxin dan folinic acid dependency terutama jika tidak terdapat faktor risiko perinatal ataupun intrapartum. ${ }^{22}$ Selanjutnya dipakai obat-obat lini kedua (Tabel 7).

Beberapa tahun terakhir ini midazolam banyak dipakai untuk mengatasi kejang, dibandingkan golongan benzodiazepin lain, midazolam paling minimal menimbulkan efek samping seperti sedasi, hipotensi dan depresi pernapasan. Beberapa penelitian menunjukkan bahwa midazolam cukup efektif sebagai obat lini kedua jika dengan fenobarbital dan fenitoin tidak teratasi ${ }^{20,21}$ Peneliti lain menyatakan bahwa

Tabel 6. Kriteria klinis pemberian obat antikovulsan pada neonatus ${ }^{8}$

\begin{tabular}{|c|c|c|c|}
\hline Tipe kejang & Karakteristik klinik & Terapi & $\begin{array}{c}\text { Konsensus atau } \\
\text { kontroversi }\end{array}$ \\
\hline \multirow[t]{2}{*}{ Fokal klonik } & Singkat dan jarang & OAE opsional & Kontroversi \\
\hline & Lama dan berulang & OAE & Konsensus \\
\hline \multirow[t]{2}{*}{ Fokal tonik } & Singkat dan jarang & OAE opsional & Kontroversi \\
\hline & Lama dan berulang & OAE & Konsensus \\
\hline \multirow[t]{2}{*}{ Mioklonik } & Singkat dan jarang & OAE opsional & Kontroversi \\
\hline & Dapat diprovokasi & Tanpa OAE & Konsensus \\
\hline $\begin{array}{l}\text { Generalized tonic } \\
\text { posturing atau }\end{array}$ & $\begin{array}{l}\text { Hilang dengan tahanan, } \\
\text { dapat diprovokasi }\end{array}$ & Tanpa OAE & Konsensus \\
\hline motor automatism & $\begin{array}{l}\text { Tidak hilang dengan tahanan, } \\
\text { tidak dapat diprovokasi }\end{array}$ & OAE opsional & Kontroversi \\
\hline
\end{tabular}

${ }^{*} \mathrm{OAE}=$ Obat anti epilepsi

Tabel 7. Kriteria EEG pemberian obat antikovulsan pada neonatus ${ }^{8}$

\begin{tabular}{ccc}
\hline Tipe kejang & Terapi & Konsensus atau kontroversi \\
\hline Kejang klinik tanpa aktifitas kejang pada EEG & Tanpa OAE & Kontroversi \\
Aktifitas kejang pada EEG tanpa kejang klinik & OAE & Konsensus \\
\hline
\end{tabular}


Setyo Handryastuti: Kejang pada Neonatus, Permasalahan dalam Diagnosis dan Tatalaksana

Tabel 8. Terapi kejang pada neonatus ${ }^{1,18}$

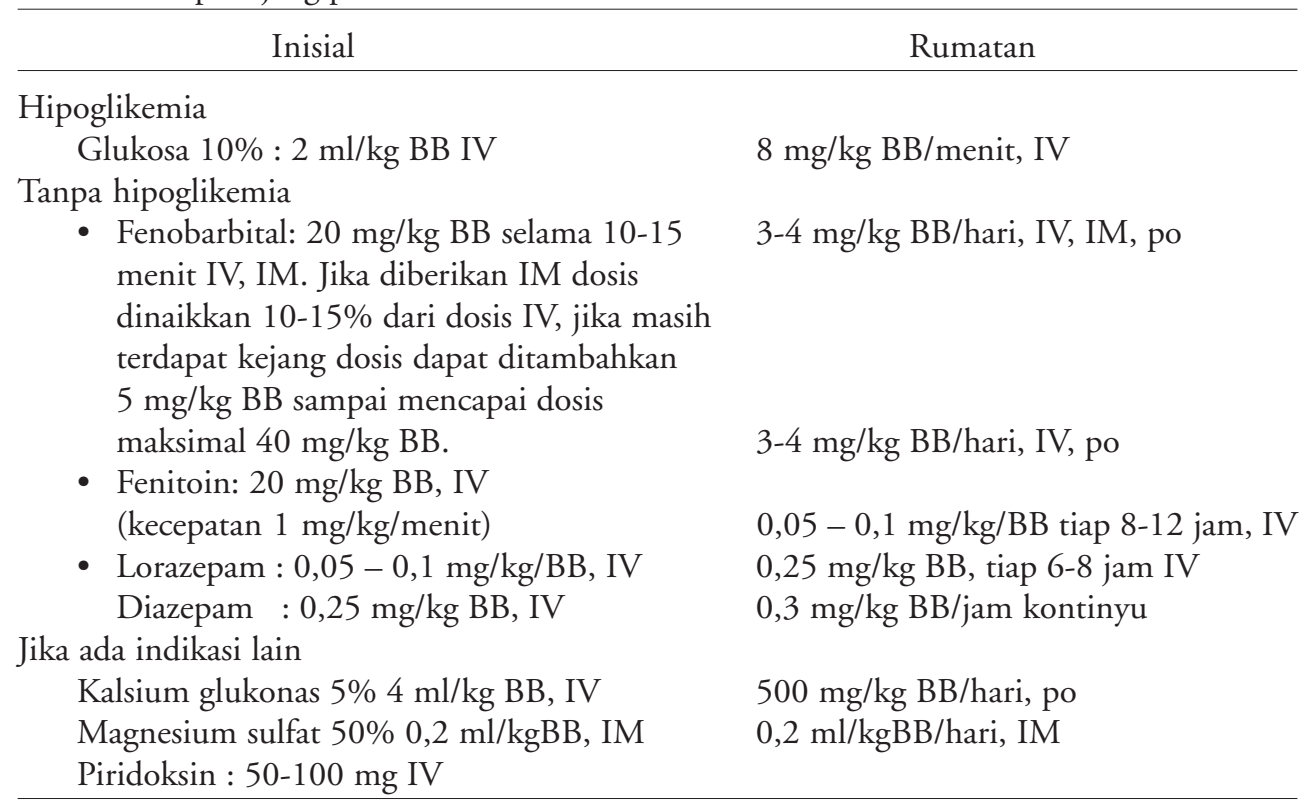

Keterangan: IV-Intervensi, IM-intro muscular, po-peroral

lignokain lebih efektif sebagai obat lini kedua dibandingkan golongan benzodiazepin. ${ }^{22,23}$ Masih banyak kontroversi seputar obat lini kedua ini karena belum adanya bukti secara ilmiah obat yang paling efektif karena belum adanya penelitian yang bersifat uji klinis acak tersamar ganda dengan jumlah sampel yang memadai. Topiramat yang termasuk golongan antagonis AMPA (alpha-amino-3-hydroxy-5-methyl-4-isoxazole proprionic acid) merupakan obat yang cukup menjanjikan karena aman dan terbukti berefek neuroprotektif terhadap hewan percobaan dibandingkan dengan obat antikonvulsan konvensional seperti fenobarbital dan fenitoin yang dapat menyebabkan apoptosis neuron pada hewan percobaan..$^{24,25}$

Lama pemberian obat antikonvulsan ditentukan oleh berapa besar risiko kejang berulang jika obat dihentikan, dan risiko terjadinya epilepsi (10\%-30\%). Faktor penentu lama pemberian terapi antara lain,

(1) Pemeriksaan neurologi, jika pada saat bayi pulang terdapat kelainan dalam pemeriksaan neurologi maka risiko berulangnya kejang sebesar $50 \%$,

(2) Penyebab kejang itu sendiri, etiologi asfiksia beresiko sebesar 30\% sedangkan disgenesis korteks beresiko $100 \%$ terhadap berulangnya kejang,

(3) Gambaran EEG, jika irama dasar memperlihatkan kelainan minimal atau ringan maka tidak dapat risiko terjadi epilepsi, jika terdapat kelainan yang
Tabel 9. Obat antikonvulsan alternatif untuk kejang neonatus ${ }^{19}$

Obat antikonvulsan intravena

Fenobarbital dosis tinggi : > $30 \mathrm{mg} / \mathrm{kg} \mathrm{BB}$

Tiopental : $10 \mathrm{mg} / \mathrm{kg} \mathrm{BB}$ dilanjutkan $2-4 \mathrm{mg} / \mathrm{kg} \mathrm{BB} / \mathrm{jam}$

Midazolam : 0,2 mg/kg BB, dilanjutkan 0,1-0,4 mg/kg $\mathrm{BB} / \mathrm{jam}$

Klonazepam: $0,1 \mathrm{mg} / \mathrm{kg} \mathrm{BB}$

Lidokain: $2 \mathrm{mg} / \mathrm{kg} \mathrm{BB}$, dilanjutkan $6 \mathrm{mg} / \mathrm{kg} \mathrm{BB} / \mathrm{jam}$

Asam valproat : $10-25 \mathrm{mcg} / \mathrm{kg}$ BB kemudian $20 \mathrm{mg} / \mathrm{kg}$

$\mathrm{BB} /$ hari dalam 3 dosis

Paraldehide: $200 \mathrm{mg} / \mathrm{kg}$ BB, kemudian $16 \mathrm{mcg} / \mathrm{kg}$ per jam

Klormetiazole : Inisial infus $0,08 \mathrm{mg} / \mathrm{kg} \mathrm{BB}$ per menit

Deksametason:0,6 - 2,8 mg/kgBB

Piridoksin:50-100 mg, kemudian $100 \mathrm{mg}$ tiap 10 menit sampai $500 \mathrm{mg}$

Obat antikonvulsan oral

Pirimidon : $15-25 \mathrm{mg} / \mathrm{kgBB} /$ hari dalam 3 dosis

Klonazepam : 0,1 mg/kg BB dalam 2-3 dosis

Karbamazepin: 10 mg/kg BB kemudian 15-20 mg/kg BB/ hari dalam 2 dosis

Asam valproat : $10-25 \mathrm{mg} / \mathrm{kg}$ BB, kenmudian $20 \mathrm{mg} / \mathrm{kgBB} /$ hari dalam 3 dosis

Vigabatrin: $50 \mathrm{mg} / \mathrm{kg} \mathrm{BB} /$ hari dalam 2 dosis sdampai 200 $\mathrm{mg} / \mathrm{kg} \mathrm{BB} / \mathrm{hari}$

Lamotrigin : $12,5 \mathrm{mg}$ dalam 2 dosis

Topiratamat : $3 \mathrm{mg} / \mathrm{kg} \mathrm{BB} /$ hari

Zonisamid : $2,5 \mathrm{mg} / \mathrm{kg} \mathrm{Bb} / \mathrm{hari}$

Levetirasetam: $10 \mathrm{mg} / \mathrm{kg} \mathrm{BB} /$ hari dalam 2 dosis

Asam folinat : 2,5 -4 mg/kg BB/hari 
berat maka risiko meningkat menjadi 41\%. ${ }^{1}$ Volpe merekomendasikan jika pada saat neonatus akan dipulangkan pemeriksaan neurologi normal maka semua obat antikonvulsan dihentikan, jika abnormal pertimbangkan faktor etiologi dan dilakukan pemeriksaan EEG. Jika pemeriksaan EEG abnormal fenobarbital dilanjutkan tetapi jika EEG normal atau etiologi adalah gangguan metabolik yang bersifat sementara fenobarbital dapat dihentikan. Jika fenitoin diberikan, obat tersebut dihentikan pada saat jalur intravena dihentikan, meskipun pemeriksaan neurologi abnormal.

Bayi yang dipulangkan dengan fenobarbital, diulang pemeriksaan neurologi dan perkembangan saat usia 1 bulan, jika pemeriksaan neurologi normal fenobarbital dihentikan dalam waktu 2 minggu, jika abnormal lakukan pemeriksaan EEG dan fenobarbital dihentikan jika tidak terdapat kelainan yang bermakna pada EEG, evaluasi ulang saat usia 3 bulan jika EEG abnormal. Volpe menyatakan bahwa sedapat mungkin obat antikonvulsan dihentikan sesegera mungkin dan pada keadaan tertentu dapat diberikan sampai usia 36 bulan, hal ini karena efek fenobarbital terhadap otak yang masih berkembang masih banyak diperdebatkan. ${ }^{1}$

\section{Prognosis}

Kejang neonatus sebanyak 25\%-30\% berhubungan dengan gangguan perkembangan. Faktor penentu utama prognosis adalah etiologi, neonatus dengan disgenesis serebral serta hipoksik-iskemik sedang dan berat mempunyai prognosis yang buruk. Gangguan metabolik akut dan perdarahan subarachnoid mempunyai prognosis yang baik, sedangkan infeksi intrakranial dan IEM mempunyai prognosis yang bervariasi. $^{6}$

Karakteristik kejang juga mempengaruhi prognosis, kejang onset dini, kejang berulang dan berkepanjangan yang resisten terhadap pengobatan mempunyai prognosis yang buruk. ${ }^{6}$ Kejang tonik berhubungan dengan palsi serebral, retardasi mental dan epilepsi sedangkan kejang mioklonik berkaitan dengan retardasi mental. ${ }^{2}$ Penelitian Brunquell menunjukkan bahwa dibandingkan dengan tipe kejang yang lain kejang subtle dan tonik umum mempunyai komplikasi epilepsi, retardasi mental dan epilepsi yang lebih tinggi. ${ }^{26}$ Gambaran EEG juga merupakan faktor prognosis. Hasil EEG interiktal normal 85\% mempunyai prognosis baik, sedangkan gambaran EEG yang isoelektrik, voltase rendah atau paroksismal burst-suppression mempunyai prognosis buruk. ${ }^{6}$

\section{Kesimpulan}

Kejang pada neonatus sering sulit dikenali, langkah pertama jika menghadapi kasus tersebut adalah memastikan gejala yang tampak kejang atau bukan. Dilanjutkan dengan melihat riwayat kehamilan, persalinan, faktor risiko, tipe kejang, dan awitan dengan evaluasi diagnostik dapat ditentukan etiologi. Tata laksana selain bertujuan untuk memberantas kejang juga mengatasi etiologi. Obat antikonvulsan yang diberikan harus efektif memberantas kejang dengan mempertimbangkan efek samping obat. Pemeriksaan EEG sangat penting untuk diagnosis, menilai respon terapi, lama terapi serta menentukan prognosis. Prognosis ditentukan oleh etiologi, tipe kejang, serta gambaran EEG. Pemahaman yang baik tentang diagnosis dan tata laksana kejang pada neonatus akan membantu menurunkan mortalitas dan morbiditas.

\section{Daftar Pustaka}

1. Volpe JJ. Neonatal seizures. Neurology of the newborn. Edisi keempat. Philadelphia: W.B. Saunders Company; 2000. h. 178-206.

2. Verrotti A, Latini G, Cicioni P, De Felice C. New trends in neonatal seizures. Review article. J Pediatr Neurol 2004; 2:191-7.

3. Nunez JL, Alt JJ, Mc Carthy MM. A novel model for prenatal brain damage. Long-term deficits in hippocampal cell number and hippocampal dependent behaviour following neonatal GABAA receptor activation. Exp Neurol 2003; 181:270-80.

4. Lanska MJ, Lanska DJ. Neonatal seizures in the United States: results of the national hospital discharge survey 1980-1991. Neuroepidemiology 1996; 15:117-25.

5. Ronen GM, Penney S, Andrew W. The epidemiology of clinical neonatal seizures in Newfoundland. A population-based study. J Pediatr 1999; 134:71-5.

6. Hill A. Neonatal seizures. Pediatr in Rev 2000; 21:117-21.

7. Sheth RD. Neonatal seizures. E-medicine. 16 November 2001 (Sitasi 28 September 2005). Didapat dari:http:// www.emedicine.com/neuro/topic240.htm. 
8. Mizrahi EM, Kellaway P. Diagnosis and management of neonatal seizures. Philadelphia: Lipincott-Raven, 1997. h. 35-46.

9. Zupanc ML. Neonatal seizures. Pediatr Clin N Am 2004; 51:961-78.

10. Levene MI, Trounce JQ. Causes of neonatal convulsions. Arch Dis Child 1986; 61:78-9.

11. Lien JM, Towers CV, Quilligan EJ. Term early-onset neonatal seizures obstetric characteristics, etiologic classifications and perinatal care. Obstet Gynaecol 1995; 85:163-9.

12. Pressler RM. Neonatal seizures. E-epilepsy-Library of articles 2003. The National Society for Epilepsy. (Sitasi 28 September 2005). Didapat dari: http:// www.neurologi.org

13. BR Tharp. Neonatal seizures and syndromes. Epilepsia 2004; 43(suppl 3):2-10.

14. Hahn JS. Olson DM. Etiology of neonatal seizures. Neo Rev 2004; 5:327-35.

15. Evans D. Levene M. Neonatal seizures. Arch Dis Child Fetal Neonatal 1998; 78:F70-5.

16. De Vries LS.The role of cerebral function monitoring. Arch Dis Child Fetal Neonatal 2005; 90:201-7.

17. Domenech-Martinez E, Castro-Conde JR, HerraizCullebras T, Gonzales-Campo C, Mendez-Perez A. Neonatal convulsions: influence of the electroencephalo- graphic pattern and the response to treatment on the outcome. Rev Neurol 2003; 37:413-20.

18. Riviello Jr JJ. Drug therapy for neonatal seizures: Part 1. NeoReviews 2004; 5:215-20.

19. Riviello Jr JJ. Drug therapy for neonatal seizures: Part 2. NeoReviews 2004; 5:262-68.

20. Castro Conde JR, Hernandez Borges AA, Domenech Martinez E, Gonzales Campo C, Perera Soler R. Midazolam in neonatal seizures with no response to phenobarbital. Neurology 2005; 64:876-9.

21. $\mathrm{Hu} \mathrm{KC}$. Continuous midazolam infusion in the treatment of uncontrollable neonatal seizures. Acta Paediatr Taiwan 2003; 44:279-81.

22. Boylan GB, Rennie JM, Chorley G, Pressler RM, Fox GF, Farrer K dkk. Second-line anticonvulsant treatment of neonatal seizures a video-EEG monitoring study. Neurology 2004; 62:486-8.

23. Rennie JM. Neonatal seizures and their treatment. Curr Opin Neurol 2003; 16:177-81.

24. Sankar R, Painter MJ. Neonatal seizures. After all these years we still love what doesn't work. Neurology 2005;64:776-7.

25. Wirrell EC. Neonatal seizures: to treat or not to treat?. Semin Pediatr Neurol 2005; 12:97-105.

26. Brunquell PJ, Glennon CM, Dimario Jr FJ, lerer T, Eisenfeld L. Prediction of outcome based on clinical seizure type in newborn infants. J Pediatr 2002; 140:127-32. 